\title{
Bonhoeffer in Latin American perceptions: An inspiration to overcome structures of injustice?
}

\author{
Altmann, Walter \\ Escola Superior de Teologia (EST), São Leopoldo, Brazil \\ walteraltmann@mns.com
}

\begin{abstract}
This article traces the influence of the German pastor and theologian Dietrich Bonhoeffer on Latin American theology. In addition to indicating the access to Bonhoeffer's writings, the article attends to Bonhoeffer's reception in various Latin American countries, including in the work of the Protestant theologian Alejandro Zorzin (from Uruguay) and the Roman Catholic theologian Érico Hammes (from Brazil). The article attests to the way in which Bonhoeffer's theology is seen as a theological resource to inspire those who seek justice in their socio-political struggles.
\end{abstract}

\section{Keywords}

Bonhoeffer, Latin America, reception history, Zorzin, Hammes, justice

\section{Introduction}

The influence of Dietrich Bonhoeffer on Latin American theology has been examined by various authors, both Latin Americans and others. In Germany, for example, Paul Gerhard Schoenborn gathered testimonies and evidences of Bonhoeffers influence upon Latin Americans. ${ }^{1}$ Already in the year 1976 Julio de Santa Ana, from Uruguay, gave a lecture in Geneva about 'The influence of Bonhoeffer on the Theology of Liberation', published in the Ecumenical Review. ${ }^{2}$ In 1995, in a seminar on occasion of

1 PaulGerhardSchoenborn, Bonhoeffer in Lateinamerika: Beziehungen zwischen Dietrich Bonhoeffer und Christen und Theologie in Lateinamerika - ein Werkstattbericht. In Hermann de Buhr et al, eds., Die evangelische Kirche im Spannungsfeld von Staat und Gesellschaft, 1993, p. 395-446.

2 Julio de Santa Ana, The influence of Bonhoeffer on the Theology of Liberation. Ecumenical Review, V. XXVII, n. 2. Apr. 1976, p. 189. Also: -. Beispiel für den 
the fiftieth anniversary of Bonhoeffer's death, at the Lutheran Seminary in São Leopoldo, state of Rio Grande do Sul, Brazil, Nélio Schneider spoke about the 'signs of Dietrich Bonhoeffer's theology and witness in Latin America'. And in 2007 Luciana Soares Ramos wrote a lengthy dissertation for a master's degree in Theology, at the Methodist University in São Bernardo do Campo, state of São Paulo, Brazil, on 'The reception of Dietrich Bonhoeffer's theology in Latin America'. ${ }^{4}$ I am indebted to these researchers.

Seventy years after his execution by the national socialist regime in Germany, the influence of Dietrich Bonhoeffer on the theological and ecclesial scene in Latin America remains considerable, as it was from the 1950's onwards, although this latter affirmation has to be looked at somewhat more carefully, as we will see.

\section{Access to Bonhoeffer's works in Latin America}

Bonhoeffer's importance can be seen already by the continuous publication in this continent of his best-known works. Let us take the example of Brazil. The 'Cost of discipleship' (Nachfolge) runs today in its $12^{\text {th }}$ edition, 'Temptation' (Versuchung) in its $9^{\text {th }}$ edition, 'Life together' (Gemeinsames Leben) also in its $9^{\text {th }}$ edition, and 'Ethics' (Ethik) in its $10^{\text {th }}$ edition. As to the 'Letters from prison' (Widerstand und Ergebung), the first work by Bonhoeffer to be published in Brazil, in 1963, it had several new editions until 2003, when the full version, made available in Germany in 1998, was published also in Brazil, and a second edition of this work has been published in this year 2015. (A first, rather brief, selection of the letters from prison had been published in Buenos Aires, Argentina, in 1956, by Rodolfo Obermüller. ${ }^{5}$ )

Widerstand - Bonhoeffers Wirkung in Lateinamerika, Evangelische Kommentare (12):646-649, 1979.

3 Nélio Schneider, Sinais da teologia e do testemunho de Dietrich Bonhoeffer na América Latina. Estudos Teológicos, 35 (1995/3): 246-257.

4 Luciana Soares Ramos. A recepção da teologia de Dietrich Bonhoeffer na América Latina. São Bernardo do Campo, 2007, 161 p.

5 Bonhoeffer, Dietrich. Cartas y apuntes de la prisión. Cuadernos Teológicos, v. 05, n. 17, p. 42-61, 1956. 
Let us also take into account that in Latin America, being constituted by countries with Spanish and Portuguese as official languages, the access to the works of European and North American theologians were very limited in earlier decades and restricted to those who were knowledgeable of German or English. The first written account in Latin America on Bonhoeffer's life and theology, still in German, seems to be registered in 1948 in the first issue of the theological review Estudos Teológicos, published by the Lutheran seminary in São Leopoldo, reproducing materials of a seminar on Bonhoeffer held by the teachers at theological seminaries in Württenberg, Germany, in August 1947. ${ }^{6}$ Thus, the 'discovery' of Dietrich Bonhoeffer in Latin America occurred only after the Second World War and Bonhoeffer's death.

Here a word about Ernest Johannes Bernhoeft should be said, with reference to a particularly sad decision taken by leaders of the Lutheran Church in Brazil. Bernhoeft, a German with Jewish roots, born in 1917, immigrated to Brazil in 1936. He became a teacher, having studied at the Lutheran seminary for teachers. Having worked as a teacher in several schools, he intended to become a Lutheran pastor, but was not accepted by the church leadership, most probably fearing negative reactions might occur within Lutheran congregations given his Jewish ancestry. Bernhoeft received the recommendation, in wishing to become a minister, of seeking another church. He felt, of course, deeply hurt. He then became an Episcopal Anglican priest.

In the early 1950's, while temporarily in Germany, Bernhoeft became acquainted with Dietrich Bonhoeffer's theology and also got to know Eberhard Bethge. Back in Brazil, he eventually translated the first edition of Bonhoeffer's letters from prison (Widerstand und Ergebung) and of the Bonhoeffer's meditations on temptation, already mentioned, and also wrote a brief biography of Dietrich Bonhoeffer, which was published in 1965 with a preface by Eberhard Bethge.

6 Dietrich Bonhoeffer. Tagung der Lehrer an den Württenbergischen Theologischen Seminaren: Am 27. und 28. August 1947. Estudos Teológicos. Studien und Berichte, n. 1, 1948.

7 Ernesto J. Bernhoeft, No caminho para a liberdade: Vida e obra de Dietrich Bonhoeffer. Rio de Janeiro: Casa Publicadora Batista, 1965-66. 
In 1995, at 78 years of age and already weakened by disease, he generously accepted the invitation to participate in a seminar held by the Lutheran Seminary, in São Leopoldo, on Bonhoeffer, on occasion of the fiftieth anniversary of his death. He gave a moving personal testimony on his personal journey, shared a few poems he had written inspired by Bonhoeffer, and received the long due sign of repentance and recognition by a Lutheran institution in Brazil. ${ }^{8}$

\section{Bonhoeffer's influence in Latin America}

Let us come back to the origins of the acquaintance of Latin Americans with Dietrich Bonhoeffer. In Brazil we have to mention first of all the teaching of Richard Shaull, a Presbyterian theologian from the United States, who came to Brazil in 1952, after having been in Colombia, to teach at the Presbyterian Seminary in Campinas, State of Sao Paulo. Richard Shaull would later become known as the proponent of a theology of revolution and has to be considered as one of the forerunners of the Latin American theology of liberation. He called the attention to Bonhoeffer's life witness and to his works, mainly 'The cost of discipleship' and 'Letters from prison'. Shaull eventually became the strongest inspiration to the ecumenical student movement in Latin America. A whole generation of participants of the ecumenical student movement in Latin American, myself included, were deeply influenced by Richard Shaull and then also by discovering Bonhoeffer.

In Buenos Aires, Argentina, quite a number of theologians were disciples of Paul Lehman, who had become a close friend to Bonhoeffer when being in the US. Thus, also via Paul Lehmann, Bonhoeffer would become known and relevant in Latin America. Finally, we should mention Eberhard

8 This is true, even though Bernhoeft personally in the late 1960's and in the 1970's, already living in Brasilia, the country's capital, assumed a very moderate, if not supportive, position in relation to the military regime. He made efforts of mediating between Brazilian authorities, even establishing personal contacts with the Presidents (army generals) Médici, Geisel and Figueiredo, and family members of persons who were suffering the oppression of the military regime. (Cf. Luciana Soares Ramos, op. cit., p. 80-84). Ramos refers to the autobiographical booklet by Bernhoeft, under the significant title of, in translation, 'A sojourner in between two worlds' (Ernesto J. Bernhoeft, Caminhante entre dois mundos, [Porto Alegre:] Metrópole, 1995 [?]) and concludes that he 'was forced by the circumstances to remain in an ambiguous position'. 
Bethge's visit to São Leopoldo, Brazil and Buenos Aires, Argentina, to lecture on Bonhoeffer, in 1970. At that time, Brazil was already ruled by a military dictatorship, a fate that would later reach so many other Latin American countries. This made the life witness and theology of Dietrich Bonhoeffer particularly relevant and challenging for Bethge's listeners.

The students and young pastors in the 1950's and especially in the 1960's were particularly challenged by the way Bonhoeffer called to the Christian involvement in the world, that the Christians, if they wanted to be faithful to their calling, could not remain confined in private spirituality or in the inner walls of an established and accommodated church. Bonhoeffer's perceptions on secularization, the distinction between faith and religion, and his affirmation that God was to be found in the centre of life, all of it seemed to make much sense and was received with enthusiasm. They concluded that they, too, had to leave the secure building of the institutionalized church and move into the crude reality full of risks 'realidade', reality, became an important word, in order to exercise love towards those who suffered injustices, in order to be there for others.

Of course, it also had heavy political consequences. Bonhoeffer's emphasis on a world come to maturity could be associated with the necessary commitment towards a revolutionary process, which would lead to a just society. And the Cuban Revolution, 1959, was there to stir up those expectations.

Not surprising then that still in the 1960's a group of Protestant theologians in Latin America constituted an organization, not dependent of any church they personally belonged to, called Church and Society in Latin America, known by its initial letters in Spanish, as ISAL. Among others, there were Rubem Alves, José Míguez Bonino, Emilio Castro, and Julio de Santa Ana, who would all of them become very well known as theologians and ecumenists. According to ISAL, to overcome the dualism of Church and World would be an essential contribution in the on-going revolutionary process in Latin America. Ironically and tragically, as we know, the development in Latin America that then effectively took place was the establishment of military dictatorships. The adjustment that this generation of theologians was then obliged to do was to struggle for human rights, in order to protect people from becoming victims of the oppression. 
This experience, however, brought them even closer to Bonhoeffer, closer to the suffering and death Bonhoeffer experienced.

Having mentioned Cuba, we can register there a very particular reception of Bonhoeffer. His theology was seen as a particularly helpful theological tool to stress the possibility, even more, the necessity of the Christians to engage themselves in the construction of the Revolution in the country. Secularization was seen hand-in-hand with the development towards a Socialist society, a concrete way to be there for others. Adolf Ham Reyes, Carlos Camps Cruell, and, primus inter pares, Sergio Arce Martínez are to be mentioned here. The cutting of past privileges of the churches by the revolutionary government of Cuba should not be seen as a loss, but as bringing the churches closer to Jesus. And the non-religious interpretation of Biblical concepts could serve towards greater mutual understanding and proximity of Christians and Marxists. The Reformed Church of Cuba even adopted in 1977 a very creative Church Confession, deeply shaped by this theology. ${ }^{9}$ Thus, in Cuba, rather than representing an influence towards overcoming structures of injustice, Bonhoeffer's theology functioned as a support to efforts being done to establish a system of social justice.

As much as I can see, Catholic theologians in Latin America have not had such an intimate relation with Bonhoeffer's theology. They got acquainted with Bonhoeffer after they had already taken those daring steps, after the key perceptions of an arising theology of liberation were already firmly established, like the identification with the poor, in a continent full of oppression. For Protestants Bonhoeffer played an essential role in their search of a relevant practice of faith vis-à-vis a system of unjust and oppressive structures. Differently, Catholics, who had had their practice of faith already shaped by other sources, met Bonhoeffer as a theological partner in their theoretical reflection related to the practice of faith they had adopted.

From the mid-1970's on a great number of essays on different aspects of Bonhoeffer's theology were written. They have been carefully listed by Luciana Soares Ramos in her dissertation already mentioned. It would

9 La Constitución de la Iglesia Presbiteriana-Reformada en Cuba: Parte I: Libro de Confesiones, La Habana : Departamento de Publicaciones, Iglesia PresbiterianaReformada en Cuba, 1997. 
be impossible to refer to all of them in this short presentation, but they testify to the fact that Bonhoeffer's influence did not diminish with time. On the contrary, it became wider and ever new aspects of his theology were given attention to. In fact, Ramos made the affirmation that in Latin America Bonhoeffer was discovered and read 'from the back to the front'. ${ }^{10}$ This means that this reading began with the theological challenges contained in his letters from prison, backed by his life witness, and moved to the perception of discipleship in its radical character, as formulated by Bonhoeffer already in 1937, and the Christological undergirding and the ethical implications of his positions.

From the 1980's on there has been also a keen interest by more conservative or pietistic and evangelical circles, especially in the books 'Cost of discipleship' and 'Life Together', and even Catholic theologians have highlighted with appreciation Bonhoeffer's mysticism. Thus, for example, the Franciscan theological review of spirituality Grande Sinal has published on several occasions spiritual exercises based on texts by Bonhoeffer. ${ }^{11} \mathrm{~A}$ book by Juan Martín Velasco even includes Dietrich Bonhoeffer, as only Protestant, among twelve Christian mysticists, alongside with the Apostle Paul, Gregor of Nyssa, Augustin, Bernhard, Francis of Assisi, Boaventura, Thomas Aquinas, Ignace of Loyola, Theresa of Jesus, João da Cruz, and Theresa of the Child Jesus. ${ }^{12}$

\section{Two fairly unknown essays on Bonhoeffer}

Before coming to the concluding remarks related to the question raised in the title of this presentation, I have selected two essays to refer more explicitly here, even though briefly, presuming they are not much known outside Latin America or even within Latin America. One is the Protestant theologian Alejandro Zorzin, from Uruguay, and the other, the Catholic theologian Érico Hammes, from Brazil.

10 Luciana Soares Ramos, op. cit., p. 133.

11 For example, Grande Sinal, Year XLVIII (1994/5), p. 626-638.

12 Juan Martín Velasco. Doze místicos cristãos: Experiência de fé e oração. [Paulo, Gregório de Nissa, Agostinho, Bernardo, Francisco de Assis, Boaventura, Tomás de Aquino, Inácio, Teresa de Jesus, João da Cruz, Teresa do Menino Jesus, Dietrich Bonhoeffer. Petrópolis: Vozes, 2003. 196 p. [Bonhoeffer, p. 171-185] 


\section{A Protestant voice}

In 1986, Zorzin, who had already previously done research in Bonhoeffer's theology, and did so also afterwards, wrote an essay on violence and peace in the theologies of Thomas Müntzer and Dietrich Bonhoeffer. ${ }^{13}$ With an undeniable sense of humor, Zorzin mentions that Müntzer and Bonhoeffer had more in common than both having been Germans and Protestants (p. 281). At the moment of their death, the movements of protest they were part of (the Church of the Reformation and the Confessing Church) had pushed them aside for considering the option they had taken not legitimately Christian (ibid.).

Zorzin did not intend to legitimize, much less to condemn, the options taken by Müntzer and Bonhoeffer, but to 'generate spaces in the theological reflection to confront hard facts, spaces where there is room for peace and for struggle, which are not ideas, but always actions' (p. 282).

I will not go into details related to Müntzer, but Zorzin develops how mystical and apocalyptical elements came together and led Müntzer, ultimately, to opt for a 'violent struggle against a violent system in itself' (287).

In relation to Bonhoeffer, Zorzin sees three phases in Bonhoeffer's thinking. The positions taken are quite different, even contradictory, but the underlying theological reasoning is the relation between what is ultimate, and what precedes the ultimate (die letzten und vorletzten Dingen). In early writings, Bonhoeffer could defend the necessity and legitimacy of war. 'The destiny of the fallen world is the absence of peace.' (292) 'For Bonhoeffer the fallen world yearns for a type of peace which itself is incapable to generate.' (ibid.) In the time preceding the ultimate, the choice may be not between good and evil, but between evil and evil. And there are situations in which you cannot love both your people and your enemies. He quotes Bonhoeffer from 1929: 'The love towards my people will sanctify the crime, will have to sanctify war. ${ }^{3}$

13 Alejandro Zorzin, La violencia y la paz en las teologías de Thomas Müntzer y Dietrich Bonhoeffer, Cuadernos de Teología, v. VII, n. 4, 1986, p. 281-301.

14 Alejandro Zorzin, op. cit., p. 294, reference to Dietrich Bonhoeffer, Gesammelte Schriften, vol. V, p. 172. Also: there are situations in which 'only through evil will it be possible to do what is good' (Dietrich Bonhoeffer, op. cit., p 175). 
In the second phase, starting in 1930, when living in the United States, he comes in contact with Christian pacifists and somewhat later participates and becomes a leader in the ecumenical student movement. Thus, already in 1932 he develops 'the possibilities of a realistic Christian ethics in favour of world peace' (295). The Church will have to proclaim God's word in as much concrete way as possible, 'not pronouncing immutable principles valid for ever, but only commandments that are valid today' (295, quoting Dietrich Bonhoeffer, Gesammelte Schriten, v. I, p. 144-145). Bonhoeffer supports the demand for world peace with a reasoning 'totally Christologicaleschatological'. In Christ, peace is both promise and fulfillment, and God's purpose is 'to preserve the fallen world until that moment in which God begins a new creation'. Bonhoeffer opts then in favour of a struggle by nonviolent means, and he even wishes to visit India, to get to know Ghandi.

In the third phase, Bonhoeffer comes to a conclusion which he develops only step by step. The basis is the perception that, confronted with totalitarian forces, which produce more and more victims, it is necessary to do something to stop the wheel of death. In 1940, then, he has come to the conclusion that it is illusionary to expect the church to take that step. Thus, he decides to join the resistance group that planned the murder of Adolf Hitler. This, too, is to be understood on the background of a radical action in the realm of what precedes what is ultimate: God's reign. And Zorzin concludes his essay referring to a passage of Bonhoeffer in his letters from prison, words written only a few days after the failed murder attempt of 20 July 1944: 'Freedom is not to escape to ideas, it exists only in action' (301).

Zorzin, certainly considering the risks implied in any attempt of this nature in a time that still had a number of military dictatorships in the continent, does not make explicit references to the Latin American situation, but his essay must be understood as an invitation to reflect, in line with Bonhoeffer's theological reasoning, about God's concrete commandments in the given situation of Latin America.

\section{Catholic voices}

Before coming to the essay by the Brazilian Catholic theologian Érico Hammes, it is appropriate, though briefly, to recall the position of the Peruvian priest Gustavo Gutiérrez, the 'father' of Latin American liberation 
theology. In his ground-breaking book Theology of Liberation (published in Spain in 1971), he made a few succinct positive references to Dietrich Bonhoeffer, without however developing any analysis of his work. ${ }^{15}$

Thus, for example, in the chapter dedicated to the 'Encounter with God in history', Gutiérrez refers to Bonhoeffer affirming that the revealed Word is not only a discourse about God and the human being, but, first of all, the Word has become flesh, so that the human history is the space in which we meet God in Christ.

But Gutiérrez would come to analyse Dietrich Bonhoeffer's theology more explicitly in an essay written in 1979 for the international review Concilium and included in his book'. The title of the essay already reveals the critical approach undertaken by Gutiérrez: The limitations of modern theology: On a letter of Dietrich Bonhoeffer. ${ }^{16}$ Already in the introduction, Gutiérrez states his aim as follows:

'I trust that by taking up the penetrating reflections of this great Christian and incisive theologian, who confronted the challenges of the modern world as perhaps no one before him, we may see both the grandeur and the historical limitations of his undertaking and thereby discern, albeit vaguely at first, another path to take.' ${ }^{17}$

Bonhoeffer's question of how to speak of God in a world come to maturity was a correct question to raise. But in assuming the world come of age in a very positive way, Bonhoeffer does not realize what it means that 'the historical agent of modern society and ideology will be the bourgeois class' (228). More: 'The protest movements of the poor, from the late Middle Ages on, find no place in Bonhoeffer's historical focus, nor does the contemporaneous labor movement' (229).

Gutiérrez does see that Bonhoeffer, when reflecting about God's presence in the world, speaks about Jesus Christ, that God does not use the instruments of domination, but takes upon Godself the weakness of the suffering on

15 See Luciana Soares Ramos, op. cit., p. 94-95.

16 Gustavo Gutiérrez, The limitations of modern theology: On a letter of Dietrich Bonhoeffer. In: -. The power of the poor in history. Maryknoll: Orbis, 1983 [Spanish original published in Peru in 1979], p.222-234.

17 Gustavo Gutiérrez, op. cit., p. 224. 
the cross. And he personally and courageously assumed the consequences for his own life. This was an intuition of the theological path to be taken. Because at the same time you would have to denounce the world's adulthood in what it has as oppression. The modern world has created 'this new world of spoliation and injustice' (231). Apparently, Gutiérrez did not feel totally comfortable with this judgement, for he recalls the earlier words of Bonhoeffer, which said:

'It is an experience of incomparable value to have learned to see the great events of the history of the world from beneath: from the viewpoint of the useless, the suspect, the abused, the powerless, the oppressed, the despised in - a word, from the viewpoint of those who suffer.' ${ }^{18}$

This is a ground-breaking intuition, and opens up new paths for action, but Bonhoeffer, according to Gutiérrez, 'never really made this insight the centre of his theological discourse' (232). And this is the limitation of this theology.

'It may be that the absence of social analysis prevented Bonhoeffer from carrying his intuition to its mature theological implications.

But he had made a beginning' (233).

In a lecture given in 1988, in Costa Rica, Franz Hinkelammert came to similar conclusions, perhaps even harder in the critique. According to him, Bonhoeffer came to the door of what would become the theology of liberation, however he did not enter. ${ }^{19}$ He concurs with Gutiérrez in saying that Bonhoeffer did not overcome his bourgeois limitations and ads to Gutiérrez' arguments that, as a result, Bonhoeffer was not able to be consequent in his critique to religion. He did not see that 'Nazism is itself explicitly a religion' (63). His theology lacks the critique of idolatry, a concept so significant for Hinkelammert and other theologians of liberation.

18 Gustavo Gutiérrez, op. cit., p. 231, quoting Bonhoeffer, Gesammelte Schriften, v. II, p. 441.

19 In: Franz Hinkelammert et al, Teología alemana y teología latinoamericana de la liberación, San José: DEI, 1990, p. 61. 
Quite different was the perception of Jon Sobrino, in his Christological works. ${ }^{20}$ Deeply shaped by his experience in Central America, in particular in El Salvador, and in distancing himself from the metaphysical Greek thought, he recalls Bonhoeffer's word in one of the letters from prison that 'Only the suffering God can be of help' (207). He then develops his thinking referring to Bonhoeffer's well-known poem on 'Christians and Heathens' (232). According to Sobrino, there is no natural knowledge of God. Together with Bonhoeffer he affirms that the cross is the critique to any natural access of the human being to God. To know God must result from meeting God in the persons who suffer.

Sobrino also underlines Bonhoeffer's perception of 'discipleship', which constitutes a central concept of Sobrino's Christology, and the critique of a cheap grace. Finally, Sobrino calls the attention to Bonhoeffer's remarks that the historical Jesus has to be understood as 'a human being for others'. When concluding that it is possible to understand Jesus only in following him within human history, alongside those who suffer, he also recognizes that Bonhoeffer did not develop this question. It is a similar critique to that of Gutiérrez, but the weights are placed differently, the positive assessment having clear precedence.

This is precisely the point which was further explored by Érico Hammes. ${ }^{21}$ He sees an 'impressive parallelism' between Bonhoeffer and Sobrino, in various aspects: 'The decisive role of following Jesus, the expansion of the realm of faith towards the socio-political real, the hermeneutic

Then, Hammes undertakes a thorough analysis of Bonhoeffer's Christology. First, already in 1933, confronted with the ascension of the Hitler regime, its interference in the life of the Church, and its ideology, Bonhoeffer raises as the central question not how, but rather who Jesus is (499). Jesus is present as the crucified and resurrected, so that the crucial aspect to be observed is that of the relation between Christ and oneself. There is a prome structure of Christ which cannot be overlooked. From there, Hammes

20 Jon Sobrino, Cristología desde América Latina. Río Hondo, México: Centro de Reflexión Teológica, 1976. See, for this section, Nélio Schneider, op. cit., p.250, and Luciana Soares Ramos, op. cit., p. 96-98.

21 Érico J. Hammes, Cristologia e seguimento em Dietrich Bonhoeffer, Teocomunicação, v. 21, n. 94 (Dec 1991): 497-515. 
detects in Bonhoeffer, as well, what he calls a 'negative Christology', namely a Christology which declares anathema to the subjugation of the Church by the State, namely, the Hitler regime.

With The Cost of Discipleship (Nachfolge), the concept of following Jesus is underlined. A cheap grace is a denial of God's living word. It is essential to accept the calling to follow Jesus, not escaping from the world, 'but confronting it with criteria other than its own'. Therefore 'the deceiving surface of a sleeping Christianity is broken and the ultimate foundations of an unconditional and unbroken faithfulness are presented' (501).

The next point developed by Hammes is that of 'being with God, in the suffering of God' (501-504). This is, according to Hammes, the third stage in Bonhoeffer's Christology. He will suffer persecution and be imprisoned. Thus, 'his permanent question of who Jesus Christ is for us today is responded practically, at the level of a faith lived out, by his uninterrupted militancy in the opposition to the Nazi regime' (502).

'If under conditions of a normal existence, following consists in an interior conformity with Christ, and Christology an explanation of Christological dogmas seen in themselves, in turbulent situations discipleship becomes conflictive and Christology militant' (Ibid.).

From there, Hammes understands Bonhoeffer highlighting God's incarnation in the human being Jesus.

'God's compassion became passion: God not only suffers with human beings, but suffers like them. To go to God after the cross, is to be with God in God's own suffering. Just as Christ is crucified in human suffering, in the cross there are multitudes of crucified persons with Him and like Him' (504).

In his conclusions, Hammes points out to the fact that Bonhoeffer's secret militancy against the given authority represents a hard challenge towards understanding. 'Yet' - and here in a footnote distancing himself cautiously from Gutiérrez-22 'there we find the greatest affinity with the theology of politics and of liberation. [...] A faith lived in status persecutionis, finds in 
the latter pages of Widerstand und Ergebung a call towards faithfulness to the real' (505). Finally,

'Christology, as listener of the Word of God and of the cry of those crucified with God, is not afraid of going itself, as well, to the cross in protest against the premature death of the innocent, be they Jews, or Blacks, or indigenous people, poor or impoverished, marginal or marginalized, unemployed or landless.'

\section{Concluding remarks}

The title of this presentation raised the question whether Bonhoeffer has served in Latin America as an inspiration to overcome structures of injustice.

We have to recognize a significant difference when comparing Protestant and Catholic theologians. While for the Protestants the encounter occurred already in the 1950's and 1960's, in the context of their search for a theological reflection that could give shape and consistency to a social involvement aimed at the transformation of evil and oppressive structures. There the inspiration of Bonhoeffer is most evident.

For Catholic theologians this involvement and commitment in social struggles was already a reality, out of other sources, when they met Bonhoeffer later on. The theological reasoning was already elaborated. They, of course, had respect and admiration for Bonhoeffer's option to resist to the ultimate consequences to the Nazi regime, but, nevertheless, the question they pursued was then to what extent they would find Bonhoeffer's theology congruent with their own and therefore helpful for the options they had made.

But this is not a fate, as the essay by Érico Hammes on Bonhoeffer's Christology, reveals. Looked at in a different perspective, and perhaps also deeper in his works, Bonhoeffer's theology reveals itself again and again with a potential of inspiring those who seek justice alongside the victims of exclusion, marginalization, discrimination, and oppression, shaping their spirituality and giving strength to their socio-political struggle. 